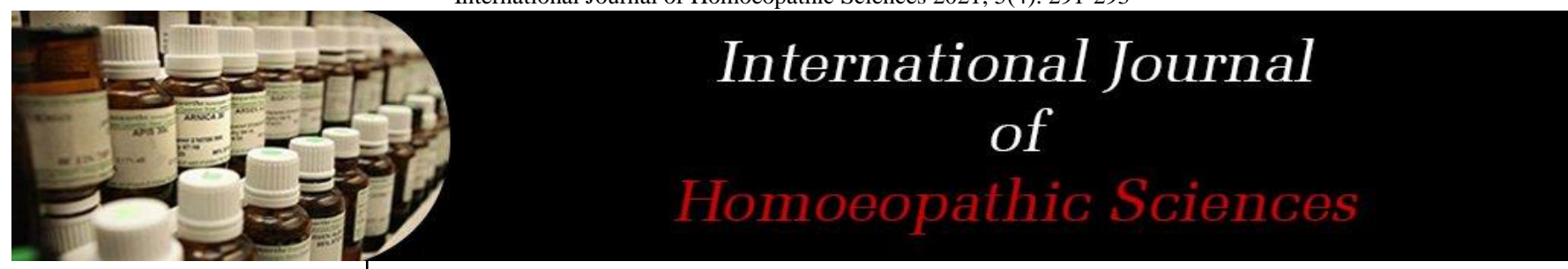

E-ISSN: $2616-4493$ P-ISSN: 2616-4485 www.homoeopathicjournal.com IJHS 2021; 5(4): 291-293 Received: 01-05-2021 Accepted: 03-07-2021

Dr. S Bidwalkar Professor and H.O.D, Department of Repertory, Dr. M.P.K. Homoeopathic Medical College, Hospital and Research Centre Sanganer, Jaipur, Rajasthan, India

Dr. Hemlata Baswal PG, Scholar, Department of Repertory, Dr. M.P.K. Homoeopathic Medical College, Hospital and Research Centre Sanganer, Jaipur, Rajasthan, India
Corresponding Author: Dr. S Bidwalkar Professor and H.O.D, Department of Repertory, Dr. M.P.K. Homoeopathic Medical College, Hospital and Research Centre Sanganer, Jaipur, Rajasthan, India

\section{Acne conglobate: An evidence-based case report treated with Individualized Homoeopathic medicine}

\section{Dr. S Bidwalkar and Dr. Hemlata Baswal}

DOI: https://doi.org/10.33545/26164485.2021.v5.i4e.485

Abstract

Acne conglobate is uncommon nodulo-cystic condition that is often resistant to therapy. The objective of this report is to support the role of homoeopathic medicine difficult to treats cases of acne conglobate.

Keywords: Acne conglobate, Hepar sulphuricum, homoeopathy, repertorisation, individualized medicine

\section{Introduction}

Acne conglobata is one of the most common skin disorders. It is uncommon nodulo-cystic condition that is often resistant to therapy. The management of this condition is difficult and usually there is temporary effect of treatment ${ }^{[1]}$. Conglobate shaped in a rounded mass or ball severe form of inflammatory nodulocystic acne characterized by numerous comedones, large abscesses or cysts interconnecting with sinuses, grouped inflammatory nodules but without systemic manifestations. These lesions frequently become secondarily infected with gram-positive bacteria and often heal with severe scarring ${ }^{[2]}$. It usually reveals inflammatory infiltrate around follicles, which run together and often form exudates/ bleed which disrupt the normal dermal architecture. The onset is usually between the ages of 18-30 years. Males are affected more often than females. In patients with acne conglobata, a significant disfigurement is common, and the scarring often results in psychological impairment and isolation from society. Suppuration, on forehead, cheeks, and neck, Occurs most frequently in young men ${ }^{[2,3,4]}$.

\section{Case Report}

A 20 years old unmarried, Hindu, vegetarian male patient visited OPD on 07 August 2017 with the complaints of red \& induration Papulo-nodular eruptions on face- both cheeks, forehead. Thick, yellow discharged from the eruptions which are painful and worsen on slightly touch.

History of presenting complaint \& treatment history: Patient was apparently well 2 years back, gradually appear eruptions on forehead and cheeks. Started appearing for which patient took Allopathic treatment and local ointment which temporally gave relief, but eruptions are recurring as soon as medicines stops.

Past history: Jaundice 3years back for which he took allopathic treatment and got relief. Family history: Mother suffering from RA

Clinical findings: Local examination - Location site: Forehead and cheeks.

Size: Various Sized Eruption.

Color: Brownish Red

Surface: Irregular.

Type of Eruptions: Pustules and Nodular

Discharge: Yellowish and tenderness present

Physical generals

- Thirst - Increase 8-10 litres /day, increased, 2-3 glasses at a time at long intervals

- Desire - Pickles 
- Aversion - Fatty food

- Stool -2 Times a day, Constipation with hard stool, much strain to expel.

- Sweat - Generalised, Profuse and offensive.

- Sleep - Patient feels sleepy but when lying down he cannot sleep as well as starting during sleep, sleep unsatisfactory.

- Thermal Reaction - Chilly

\section{Mental Generals}

- During anger very aggressive in expression.

- Weak memory.

- While case taking, Patient speaks quickly and speedily.

\section{Evolution \& Totality of symptoms}

- Aggressive during anger.

- Weak memory.

- Sleepiness but cannot sleep.

- Desire for pickles

- Aversion to fatty food.

- Sweat Profuse and offensive.

- Thermal - Chilly.

- Thirsty.

- Painful Papulo-nodular eruptions on face.

- Yellowish thick discharge with eruptions.

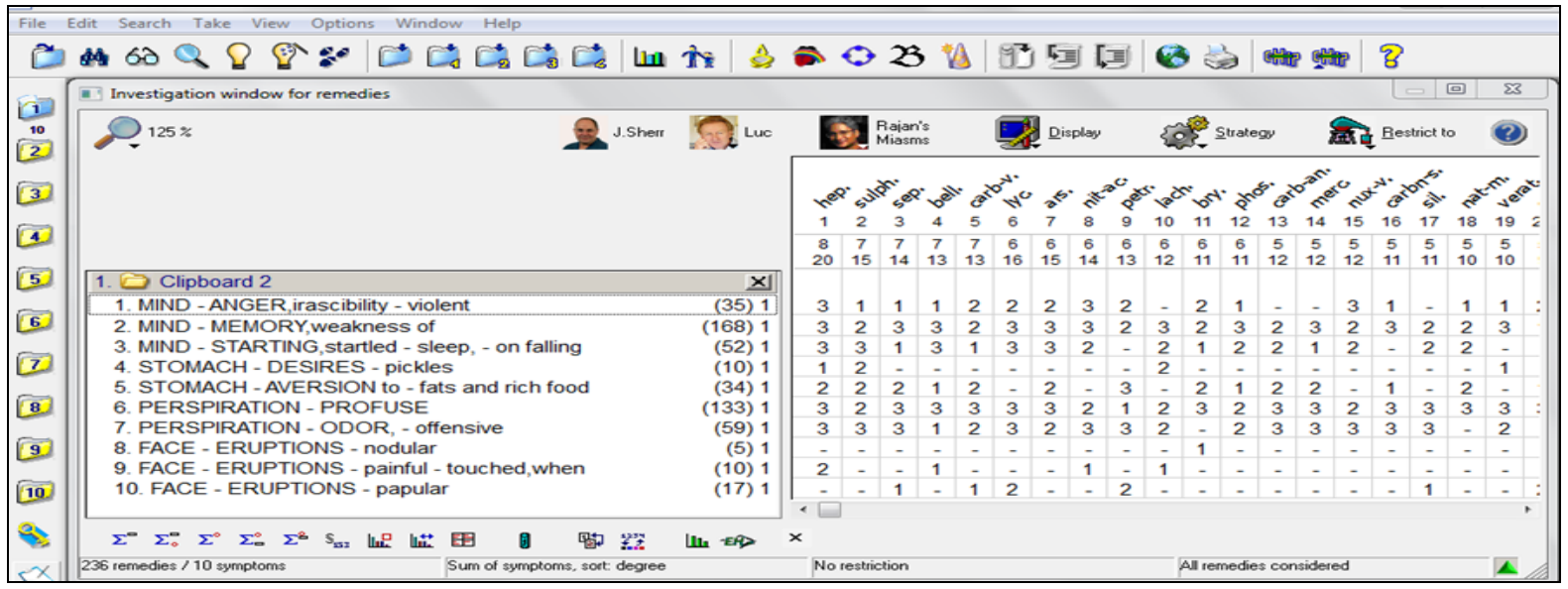

Fig 1: Figure showing Repertorial analysis (repertory sheet) of case from Kent's Repertory using RADAR software

On reportorial analysis Hepar sulph have second highest marks (20) covering most of the rubrics (8 out of 10). While Sulphur covering $(15 / 7)$.

First prescription with justification: In this case Heper sulph was prescribed after repertorization, in $30^{\text {th }}$ potency on the basis of patient's susceptibility. $30^{\text {th }}$ potency gives sufficient improvement in the treatment of chronic diseases.

Table 1: Follow - up details

\begin{tabular}{|c|c|c|c|}
\hline S. No. & Dates & Observation and Assessments & Prescription \\
\hline 1. & $15-8-2017$ & After a week redness reduced but severity of pain remained stand still & Hepar sulph 30C/BD for 1 month \\
\hline 2. & $18-9-2017$ & Gradually pain, discharge, and induration started reducing & Placebo /TDS for 2month. \\
\hline 3. & $20-11-2017$ & $\begin{array}{c}\text { After two and half month's case stood still where there remained eruptions } \\
\text { without inflammation and scar. Patient was irregular too. }\end{array}$ & $\begin{array}{c}\text { Hepar sulph 200 single dose, Placebo } \\
\text { /TDS for 15days }\end{array}$ \\
\hline 4. & $1-12-2017$ & further showed relief and went on improving & Placebo /TDS for 2month \\
\hline
\end{tabular}

Patient last reported in July 2018 with no recurrence of symptoms
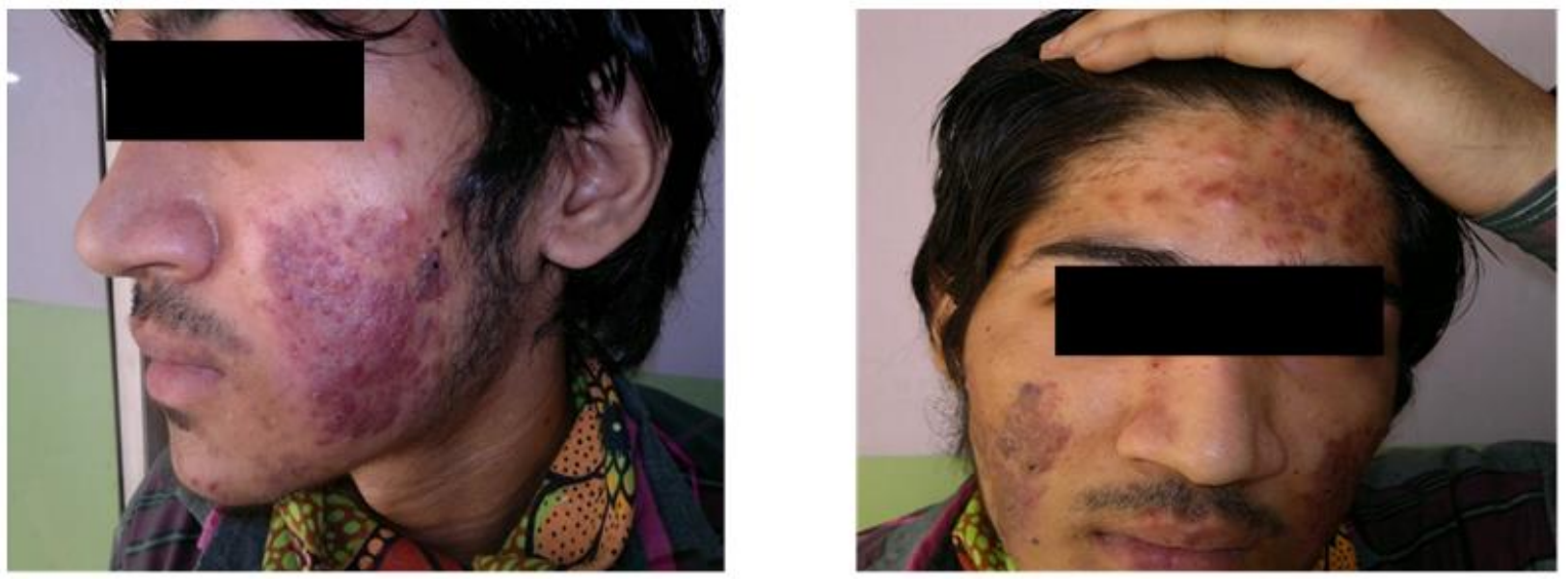

Fig 2: Before treatment 

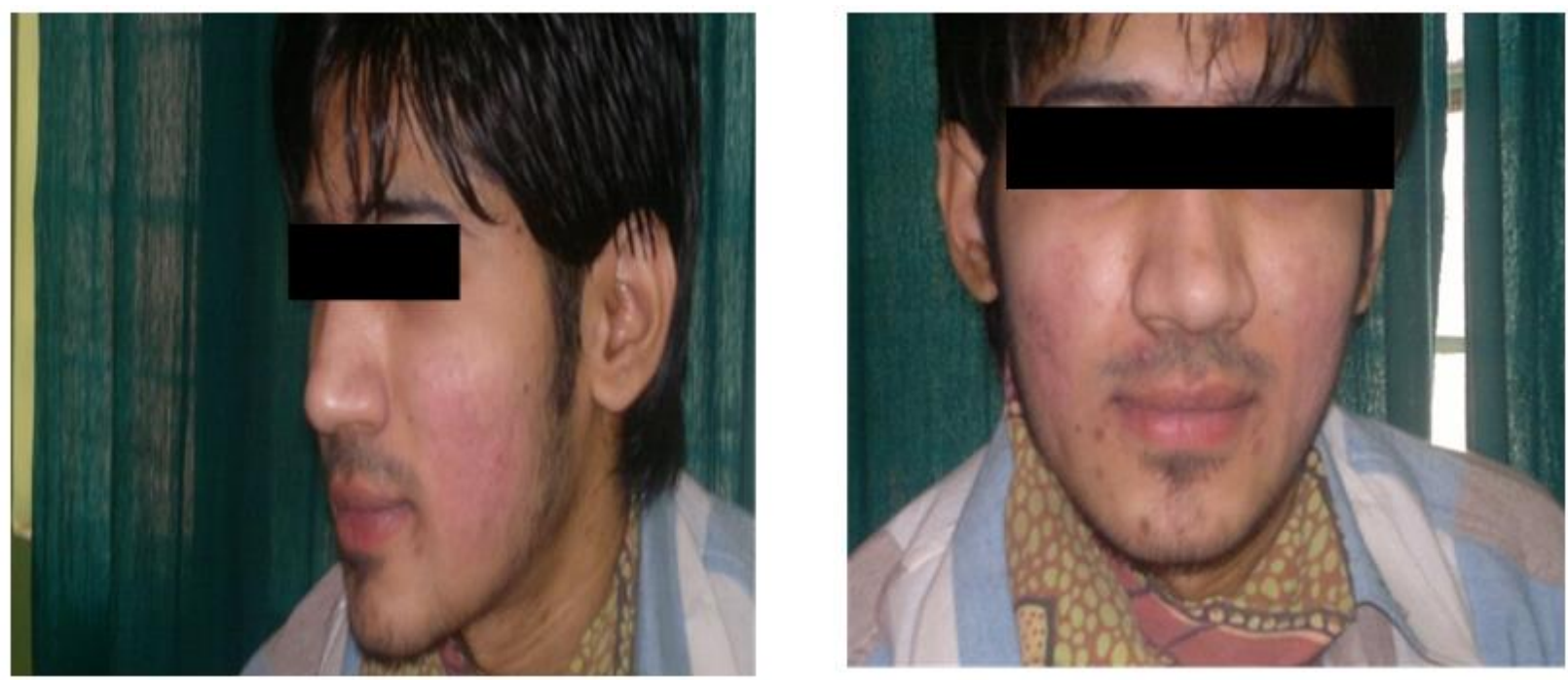

Fig 3: After treatment

\section{Discussion}

Hepar Sulphur is a homoeopathic remedy with affinity for suppurative processes and delayed healing, which is most suited in the cases where acne is painful \& sensitive and more in the form of boils \& abscesses. This remedy treats acne in adolescents, who have unhealthy skin and painful (prickly) and sensitive pimples. Homoeopathic remedy for pimples small (or often pea-shaped) and may suppurate with white pus. They bleed easily and may ulcerate if scratched or injured. Symptoms are batter by damp weather and aggravation on touching or washing, and intolerance to cold. In previous research, Hepar Sulphur in $30 \mathrm{CH}, 200 \mathrm{CH}$ potency showed significant improvement in the staphylococcus infection and acne vulgaris.

\section{Conclusion}

Homoeopathy has great action on the patient suffering from Acne conglobate. Homoeopathy has proven its effectiveness in such type of cases.

\section{References}

1. Dessinioti C, Katsambas A. Difficult and rare forms of acne.Clin Dermatol 2017;35(2):138-146. Available from: https://www.ncbi.nlm.nih.gov/pubmed/28274350.

2. Shirakawa M., Uramoto K., Harada FA. Treatment of acne conglobata with infliximab. J Am Acad Dermatol 2006;55:344-6. [doi:10.1016/j.jaad.2005.06.008]

3. Hafsi W, Badri T. Acne Conglobata. First ed. Treasure Island (FL): Stat Pearls Publishing 2018.

4. Canpolat F, Kurmuş GI, Gönül M. Acne conglobata. Ro JCED 2017;2(4):68-73 [online PDF]. Available from: https://www.researchgate.net/publication/324532340_A cne_Conglobata.

5. Das DC., Sarma T. Acne Vulgaris: Treated with Natrum muriaticum (Homoeopathic Medicine): A Case Report. Sch J Med Case Rep 2016;4(8):592-594. [DOI: 10.21276/sjmcr.2016.4.8.8]

6. Das DC, Sarma T. Utility of Homoeopathic Repertory in Treatment of Acne Vulgaris. International Journal of Science and Research 2017,6(4).

7. Boericke W. New Manual of Homoeopathic Materia Medica\& Repertory. Reprint edition. New Delhi. B. Jain Publishers (P.) Ltd 2002.

8. Pasalkar AD, Kathade SA, Jadhav $\mathrm{AB}$ et al. Study the anti-bacterial activity of homoeopathic medicines against staphylococcus epidermidis in vitro. Int. J Health Sci Res 2019;9(12):49-53. 